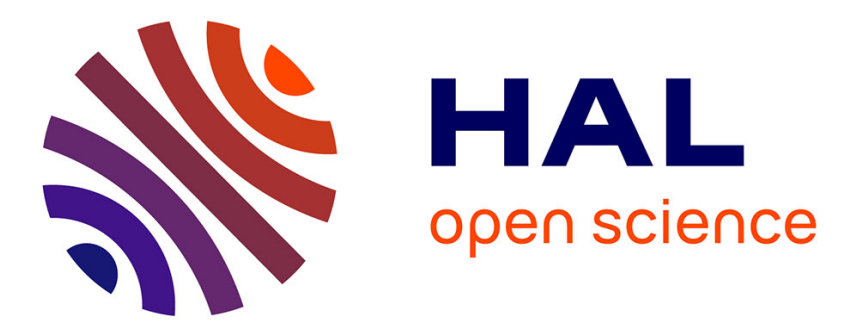

\title{
NO-synthase inhibitors induce a transient contraction of guinea pig ileum by a substance $\mathbf{P}$ dependent "non-neurokinin" receptor mechanism
}

Rafael Garcia Villar, Christelle Dupuis, Jean Fioramonti, Lionel Bueno

\section{- To cite this version:}

Rafael Garcia Villar, Christelle Dupuis, Jean Fioramonti, Lionel Bueno. NO-synthase inhibitors induce a transient contraction of guinea pig ileum by a substance $\mathrm{P}$ dependent "non-neurokinin" receptor mechanism. 1st Eur Congress of Pharmacology, Jun 1995, Milan, Italy. pp.P\#249. hal-01600589

\section{HAL Id: hal-01600589 \\ https://hal.science/hal-01600589}

Submitted on 7 Jun 2020

HAL is a multi-disciplinary open access archive for the deposit and dissemination of scientific research documents, whether they are published or not. The documents may come from teaching and research institutions in France or abroad, or from public or private research centers.
L'archive ouverte pluridisciplinaire HAL, est destinée au dépôt et à la diffusion de documents scientifiques de niveau recherche, publiés ou non, émanant des établissements d'enseignement et de recherche français ou étrangers, des laboratoires publics ou privés.

\section{다(1)(2)}

Distributed under a Creative Commons Attribution - ShareAlikel 4.0 International 


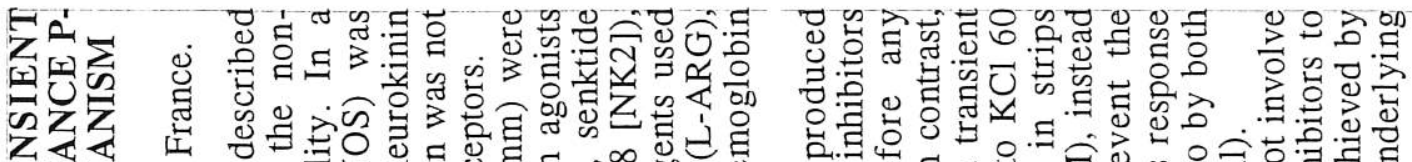

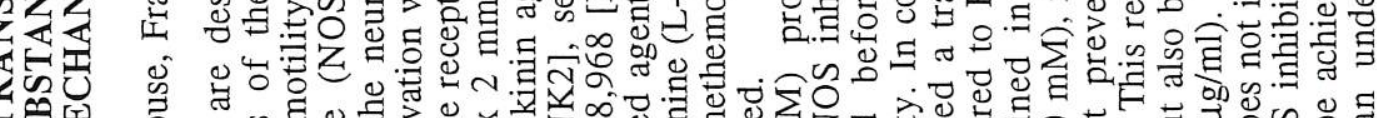

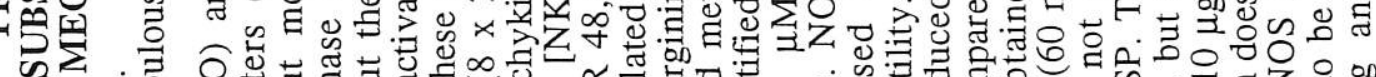

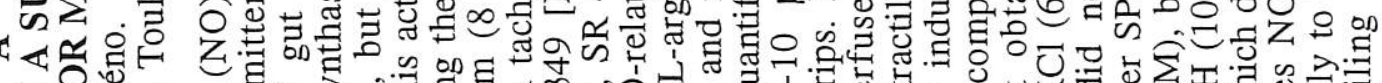

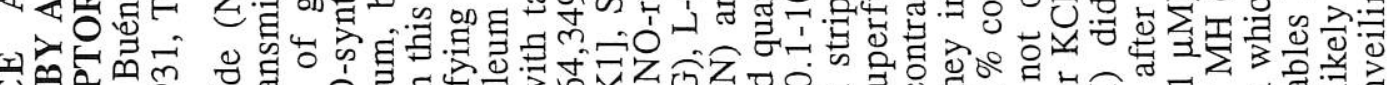
Uص口m

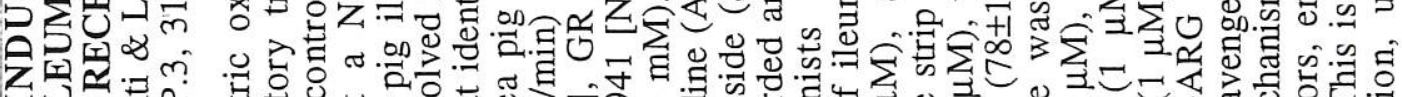

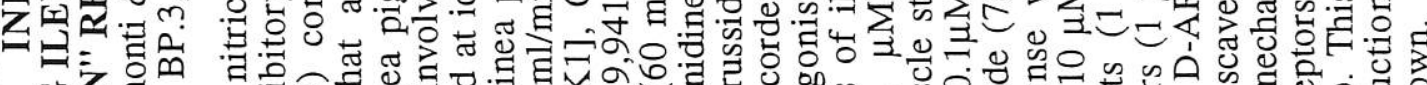

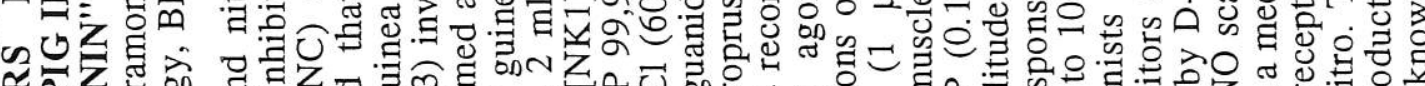

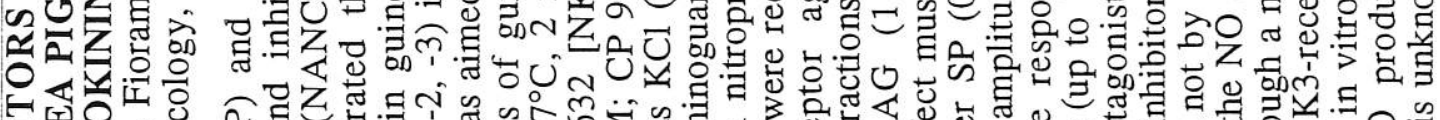

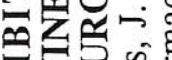

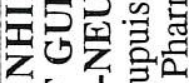

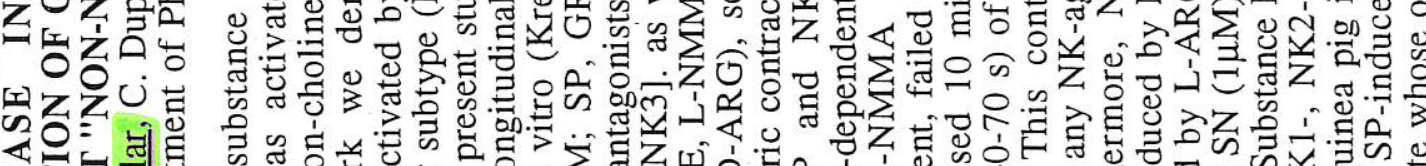

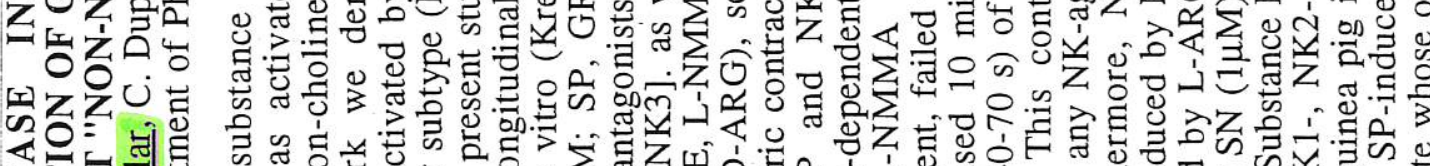

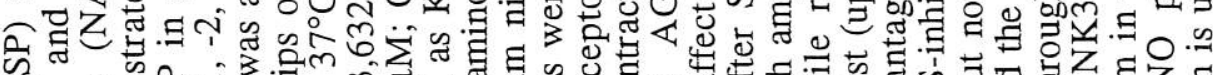

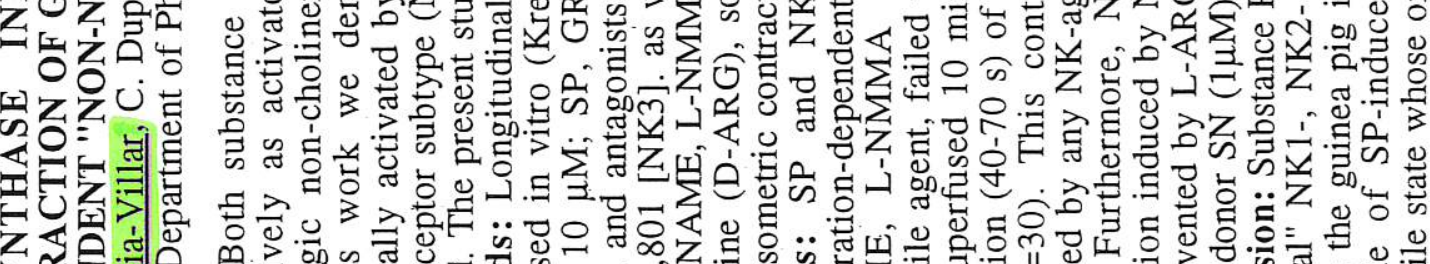

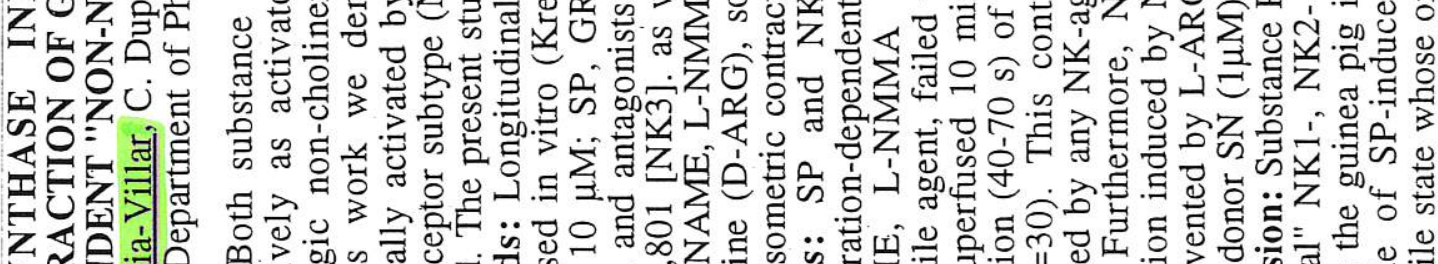

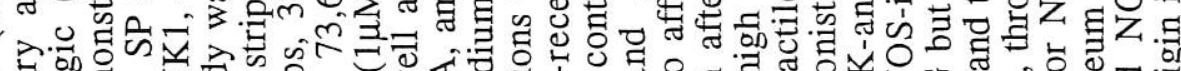

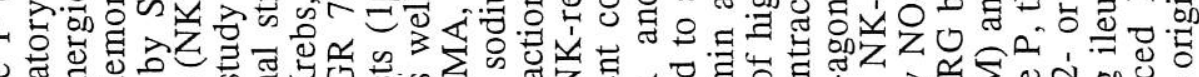

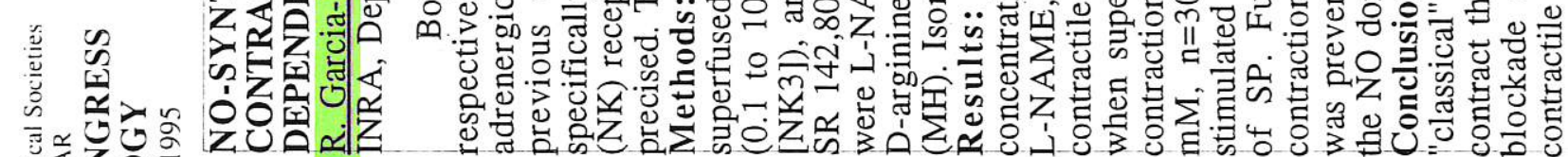

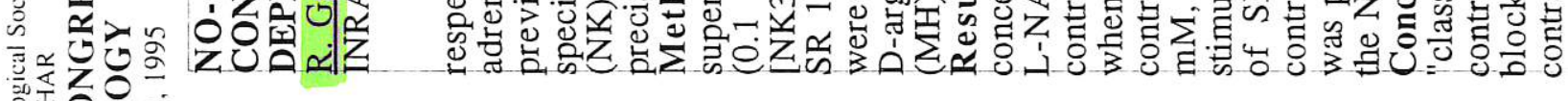

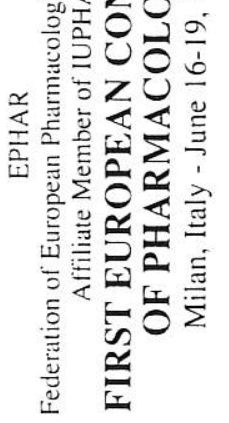

\author{
XOg $\exists \cap 79 \mathrm{HH}$ \\ NIHIIM $\exists d \lambda \perp \exists S \forall \exists 7 d$
}

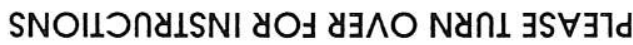
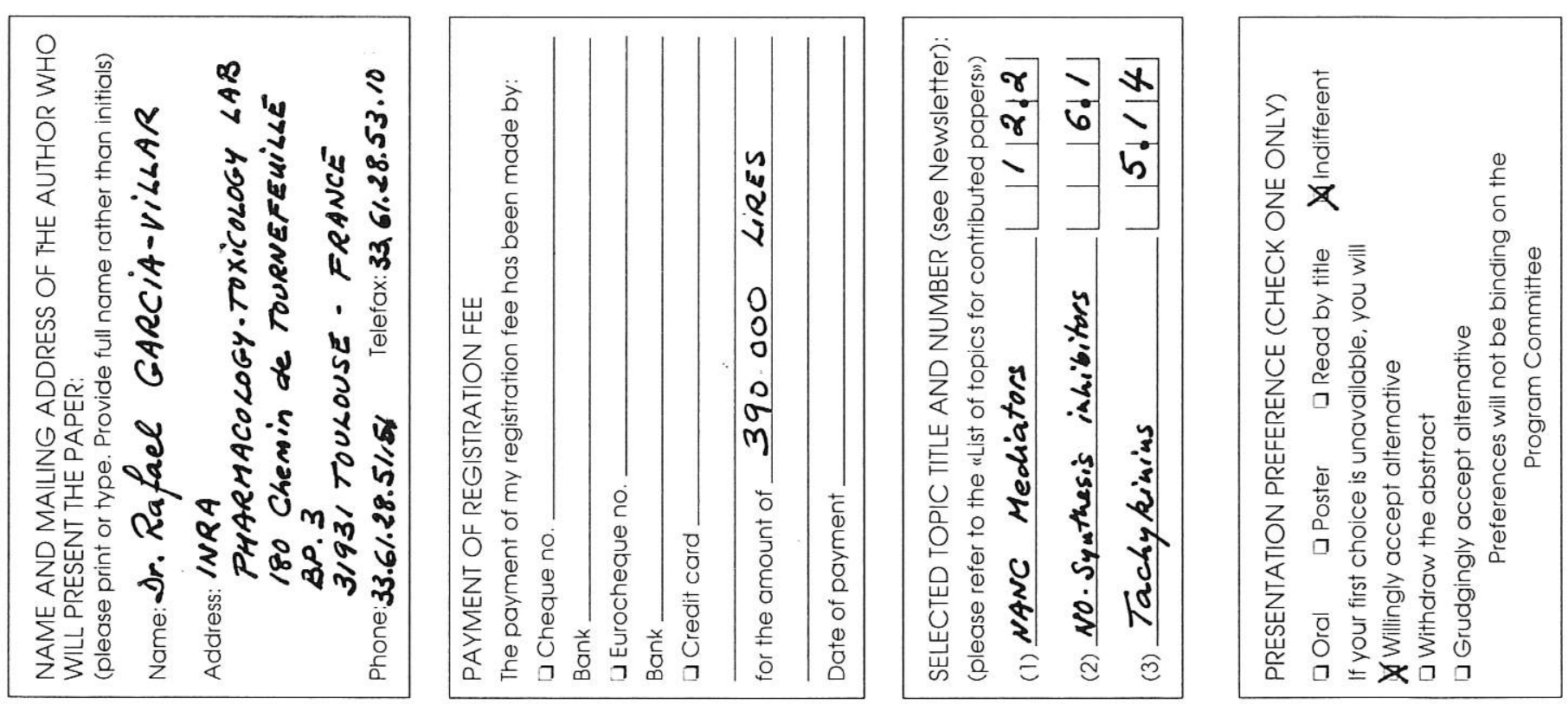

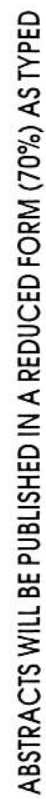


EPHAR

Federation of European Pharmacological Societies Affiliate Member of IUPHAR

\section{FIRST EUROPEAN CONGRESS OF PHARMACOLOGY}

Milan, Italy - June 16-19, 1995

\author{
Chairmen \\ W.C. Bowman (UK) \\ G. Fillion (France) \\ H. Scholz (Germany) \\ H.A.J. Struijker-Boudier (The Netherlands) \\ R. Paoletti (Italy) \\ Scientific Secretaries \\ F. Cattabeni (Italy) \\ M.P. Abbracchio (Italy)
}

Milan, April 10, 1995

Dr. Rafael GARCIA-VILLAR

INRA

Pharmacology-Toxicology Lab.

180 Chemin de Tournefeuille

BP 3

31931 TOULOUSE

FRANCE

\section{EXPRESS MAIL}

Ref.: Your submitted abstract

"NO-SYNTHASE INHIBITORS INDUCE A TRANSIENT CONTRACTION OF GUINEA..."

Dear Dr. GARCIA-VILLAR,

on behalf of the Scientific Program Committee we are pleased to inform you that your contributed paper has been accepted for POSTER presentation.

$$
\text { \# } 249
$$

Your poster has been scheduled on Saturday, June 17, 1995 in the session "GASTROINTESTINAL PHARMACOLOGY: MOTILITY".

Each poster session will have a duration of one day.

For your better information please refer to the enclosed instructions sheet.

We wish to remind you that no paper can be presented without having paid the corresponding fee; therefore, if you have not paid your registration fee yet, please do so immediately.

In case you could not attend the Congress please notify us promptly.

With our best regards.

Yours sincerely,
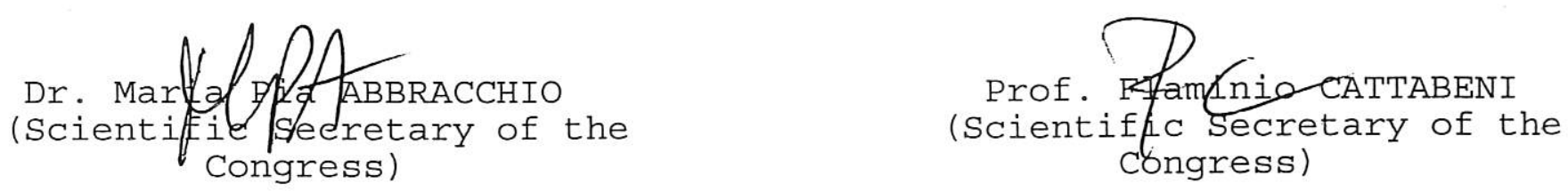

Encl.

Organizing Secretariat: 